\title{
PENERAPAN TERAPI AKTIVITAS KELOMPOK (TAK) DAN SENAM LANSIA SEBAGAI UPAYA PENGENDALIAN DEMENSIA PADA LANSIA
}

DOI: https://doi.org/10.33024/jkpm.v4i4.3959

\author{
Ganda Sigalingging ${ }^{1 *}$, Zulkarnain Nasution ${ }^{2}$, Hetti Marlina Pakpahan ${ }^{3}$, \\ Nasilia Tafonao ${ }^{4}$ \\ ${ }^{1-4}$ Fakultas Ilmu Keperawatan Universitas Darma Agung Medan \\ Disubmit: 05 Maret 2021 Diterima: 07 April $2021 \quad$ Diterbitkan: 03 Agustus 2021
}

Email Korespondensi: gandabonagabe@gmail.com

\begin{abstract}
ABSTRAK
Ancaman triple burden merupakan tantangan yang harus dihadapi di Indonesia, diantaranya jumlah lansia yang terus meningkat. Seiring pertambahan usia, berpotensi menimbulkan masalah kesehatan fisik dan psikososial antara lain depresi, harga diri rendah, bahkan bunuh diri, jika tidak ditangani dengan serius. Oleh karena itu, diperlukan upaya mempertahankan kesehatan lansia pada taraf kesehatan optimal. Tujuan untuk meningkatkan kemampuan lansia berinteraksi dalam rangka pencapaian penyesuaian psikologi, perilaku dan pencapaian adaptasi optimal. Metode kegiatan melakukan senam sehat dan terapi aktivitas kelompok (TAK). Hasil kegiatan menunjukkan, secara keseluruhan lansia terlihat ceriah dan bahagia. Disimpulkan kegiatan ini mampu meningkatkan semangat dan menciptakan kebersamaan sesama lansia selama berada di rumah Jompo. Kepada Yayasan panti jompo untuk memfasilitasi kegiatan sesuai kebutuhan lansia yaitu melakukan terapi aktivitas kelompok (TAK) dengan senam sehat secara berkesinambungan untuk tercipta perasaan yang riang gembira sehingga kualitas hidup lansia tetap sehat, mandiri, berguna, dan produktif.
\end{abstract}

Kata kunci : Terapi aktivitas kelompok, senam sehat, demensia, lansia.

\begin{abstract}
The triple threat is a challenge that must be faced in Indonesia. More and more the number of elderly that continues to increase. As you age, changes occur due to the aging process that causes physical and psychosocial problems. one of the psychosocial problems in the elderly is low self-esteem. If that doesn't work, the elderly will repair, attract, challenge, and even escape. Therefore, it is necessary to maintain the health of the elderly at an optimal level of health. The goal is to increase the ability of elderly in the contexs of psychological loss, behavior and optimal adaptation. Activity methods of doing healthy gimnastics and group activity therapy. The results of activity showed that overall the elderly looked bright and happy. This activity can increase enthusiasm and create togetherness among the elderly in a nursing home.
\end{abstract}

Keywords: Group activity therapy, healthy gimnastics, dementia, elderly. 


\section{PENDAHULUAN}

Seiring dengan semakin meningkatnya populasi lanjut usia akan membawa dampak di berbagai aspek kehidupan lansia. Salah satu aspek terpenting adalah masalah kesehatan, bukan saja hanya penyakit kronis atau penyakit degeneratif, melainkan juga kerentanan terhadap infeksi dan masalah psikosoail.Salah satu masalah kesehatan yang paling umum terjadi pada kelompok lansia adalah demensia. Demensia merupakan kemunduran kognitif yang sedemikian beratnya, sehingga mengganggu aktivitas sosial dan pekerjaannya (Azizah, 2011)

Berdasarkan data Riskesdas (2016) di Indonesia jumlah Orang dengan Demensia (ODD) pada tahun 2013 mencapai satu juta orang, diperkirakan akan meningkat dua kali lipat pada tahun 2030, dan menjadi empat juta orang ditahun 2050. Hasil penelitian Ganda (2020) Harga diri (self esteem) Lansia yang Mengalami Demensia di yayasan guna budi bakti medan sebanyak $44,4 \%$ mengalami demensia sedang, dan menunjukkan harga diri rendah sebanyak 69\%. Dengan kelompok umur antara 50 sampai 80 tahun keatas. Hasil penelitian Apriance(2018) Hubungan Demensia Dengan Kebermaknaan Hidup Pada Lanjut Usia Di BPLU Senja Cerah Provinsi Sulawesi Utara terdapat dari 33 responden, lansia yang mengalami demensia ringan $(36,4 \%)$ lansia yang mengalami demensia sedang $(45,5 \%)$ demensia berat $(18,2 \%)$ dengan kelompok umur diatas 60 Tahun. Penelitinan Sigalingging (2019) bahwa lansia di Panti Harapan Jaya marelan, lansia lebih banyak mengalami insomnia sebanyak $59 \%$, mengalami depresi $48,5 \%$. Hal ini memberi arti, bahwa pada masa lansia timbul berbagai permasalahan yang memerlukan berbagai upaya untuk meningkatkan kualitas hidup lansia.

Menurut Nugroho (2008) lansia akan mengalami banyak perubahan dan penurunan fungsi fisik dan psikososial. Perubahan ini dapat menimbulkan berbagai masalah pada lansiayang akan berpengaruh dalam menilai dirinya sendiri. Harga diri menjadi hal yang sangat penting bagi lansia karena harga diri adalah rasa dihormati, diakui, diterima dan bernilai bagi lansia yang didapatkan dari orang lain Potter dan Perry (2009). Harga diri rendah adalahsuatu evaluasi diri yang negatif dan berhubungan dengan perasaan yang lemah, tak berdaya, ketakutan,tidak berharga, dan tidak memadai Azizah, (2011)

Menurut hasil penelitian Potter (2009) di Amerika Serikat, ditemukan bahwa sebanyak $26 \%$ orang yang berusia 60-80 tahun keatas mengalami harga diri rendah. Demikian juga hasil penelitian Nanthamongkolchai Tuntichaivanit (2009) di Propinsi Nakhon Sawan menunjukkan bahwa 19,3\% lansia mengalami harga diri rendah. Menurut Syam' ani (2011), lansia yang mengalami harga diri rendah emiliki perasaan malu, kurang percaya diri, minder, tidak berguna, tidak mampu, menyalahkan diri, menarik diri, dan keinginan yang tidak tercapai misalnya berkumpul dengan keluarga.

\section{MASALAH}

Berdasarkan wawancara dengan petugas Panti Jompo yayasan Guna Budi Bakti didapatkan bahwa jumlah lansia sebanyak 72 orang, rata-rata lansia mengalami masalah dengan ingatan (demensia). Sebagian besar lansia menunjukkan perubahan perilaku misalnya mudah marah, mudah menangis, lupa dengan sesuatu, cenderung menghindar dari lingkungan sosial, menolak untuk bergabung dengan kelompok lansia lain pada saat melakukan kegiatan, lansia tidak mampu menyesuaikan diri dan hipersensitif terhadap kritikan orang. Bahkan ada lansia mengeluh merasa diri tidak berguna. Untuk itu, perlu suatu upaya untuk dapat menyemangati lansia yang mengalami demensia. 


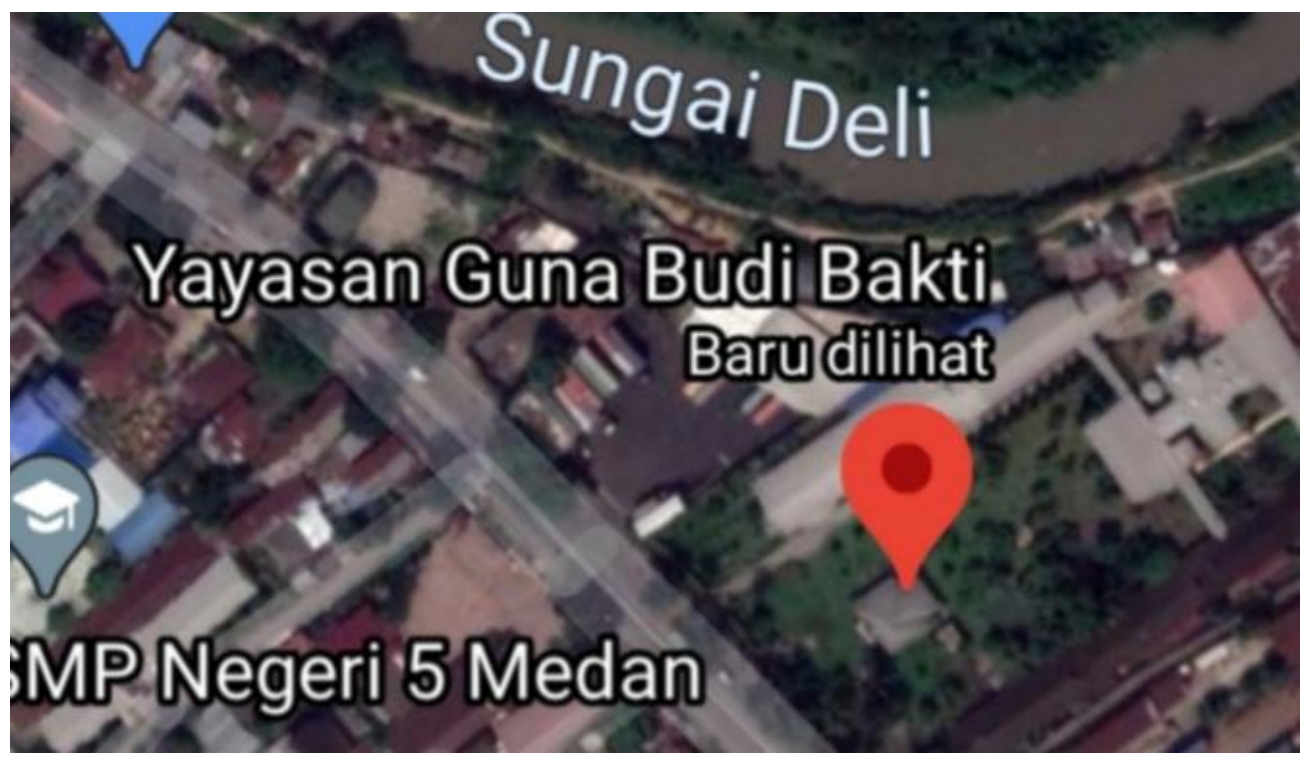

Gambar 2.1.Lokasi Yayasan Guna Budi Bakti

\section{METODE}

Beberapa masalah yang Umum terjadi pada lansia yang tinggal dipanti jompo kurang merasa hidup bahagia, merasa kesepian karena jauh dari keluarga, cendrung merasa kurang memaknai hidup, kurang semangat dan merasa kesepian dan hampa. Secara umum, penyebab timbulnya masalahpada lansia yaitu disebabkan oleh kondisi penurunan fisik yang memang muncul dari proses penuaan yang terjadi. Pada lansia yang tinggal di pati jompo masalah yang sering muncul yaitu masalah sosial akibat keterbatasan perawatan dan peran keluarga yang merawatnya. Masalah sosial yang dimaksud yaitu kesepian, stess, depresi, penarikan diri, merasa harga diri rendah, dan acuh tak acuh terhadap diri dan lingkungan.berdasarkan masalah tersebut, maka metode yang digunakan dalam kegiatan ini adalah:

1. Tahap Persiapan.

Tahap persiapan dari kegiatan ini adalah pembuatan pre planing, persiapan kegiatan: persiapan tempat sesuai jenis kegiatan, persiapan media (musik, speaker, gambar dan lagu untuk TAK), menyiapkan alat pengukur tekanan darah, di siapkan oleh tim PKM.

2. Tahap Pelaksanaan Kegiatan .

Kegiatan pengabdian masyarakat dilaksanakan tanggal 8 Sepember 2019 dimulai pada pukul 08.30. Kegiatan ini dihadiri oleh 52 orang lansia yang ada di Rumah Jompodengan status kesehatan mandiri dan parcial care dengan usia 60 tahun ke atas. Pelaksanaan kegiatan, di awali pengukuran tekanan darah terhadap 19 Orang lansia (sesuai kondisi) dilanjutkan senam sehat, dimulai pukul 08.30 sampai 09.30, pukul 09.30-10.00 rehat snack sekaligus pembagian kelompok. Pukul 10.00 sampai 11.30 penjelasan strategi bermain meliputi: tujuan, manfaat, dan cara permainan di lanjutkan dengan pelaksanaan TAK (tebak gambar, judul lagu tembang kenangan di ikuti pemberian hadiah kepada pemenang. Selain pemenang, untuk menyemangati lansia semua peserta diberikan hadiah juga. Untuk mengakhiri kegiatan, para peserta diberikan leafleat edukasi berisi gambar buah segar, gambar lansia ceriah dan foto bersama.Seluruh tim 
terlibat dan berperan aktif dalam kegiatan pengabdian masyarakat peserta juga antusias, ceriah dan menunjukkan semangat yang tinggi selama kegiatan berlangsung.

3. Evaluasi .

1. Evaluasi Struktur

Jumlah peserta sebanyak 52 orang terdiri dari laki-laki dan perempuan. Sebagian dari lansia ada menggunakan kursi roda, sehingga kegiatan disesuaikan dengan kondisinya. Setting tempat sudah sesuai dengan yang direncakaan, segala keperluan kegiatan sarana prasarana sudah tepat saling mendukung, sehingga kegiatan benjalan dengan lancar. Setiap tim sudah melakukan tugas sebagaimana uraian tugas masing-masing yang ditetapkan sebelumnya. Baik itu leader, Co leader, fasilitator, observer, dan dokumentasi. Selama berlangsung kegiatan, penerapan komunikasi terapeutik juga terlihat, hal ini dibuktikan 90\% lansia, tertarik dan mengikuti kegiatan sampai selesai.

2. Evaluasi proses.

Pelaksanaan kegiatan, sesuai dengan yang direncanakan baik dari segi waktu pelaksanaan, kehadiran, jumlah peserta dan kesiapan tim PKM. Tim kegiatan pengabdian masyarakat hadir tepat waktu dan berperan sesuai dengan perannya dan dapat memfasilitasi peserta selama kegiatan berlangsung hingga kegiatan selesai.

\section{HASIL DAN PEMBAHASAN .}

Pelaksanaan kegiatan pengabdian kepada masyarakat berupa penerapan terapi aktivitas kelompok (TAK) dan senam sehat pada lansia di rumah jompo. Berikut beberapa bentuk kegiatan yang dilakukan dan respon lansia selama kegiatan.

1) Melakukan pengukuran tekanan darah terhadap 19 orang lansia parcial care. Hasil pengukuran tekanan darah dalam batas terkontrol. Dilanjutkan dengan senam sehat. $100 \%$ lansia mengikuti senam dengan aktif sesuai kemampuan.

2) Memberikan penjelasan/edukasi tentang kegiatan meliputi: jenis kegiatan, tujuan, manfaat, dan cara permainan, di lanjutkan dengan pelaksanaan TAK.

3) Menebak gambar buah : pisang, pepaya, mangga, durian dan apel yang sudah di siapkan tim PKM yang di model semenarik mungkin pada lembar kertas karton manila, kemudian lansia diberikan kesempatan untuk menyebutkan nama buah tersebut dengan waktu yang telah ditentukan. Lansia yang mampu menebak gambar, langsung diberikan buah sesuai gambar, sambil di iringi musik. 95\% lansia tertarik dan sangat antusias mengikuti kegiatan. Adapun buah yang sangat disenangi lansia adalah buah pisang, dengan alasan pisang rasanya pasti manis, lembut, warnanya cantik dan menggugah selera.

4) Tebak judul lagu yang telah direkam sebelumnya : lagu tembang kenangan dan lagu nostalgia. Aturan permainan sama. Lansia yang menebak judul lagu yang dengan tepat, diberikan kesempatan untuk menyanyikan lagu terbut di dampingi lansia lain yang 
merupakan teman dekatnya. Hampir $90 \%$ lansia senang dan ekspresi lansia menunjukkan kebahagiaan, terharu bahkan ada yang menangis mengingat masa lalu bersama orang yang dicintai.

5) Tebak nama tim PKM yang sudah diperkenalkan sebelumnya dengan ciri khas yang dimiliki (ramah, pendiam, senang memerintah). $85 \%$ lansia sangat menyenangi sifat ramah, dan $98 \%$ lansia tidak suka dengan sifat senang memerintah. Hal ini membuktikan bahwa lansia sangat membutuhkan keperdulian, dihargai, bukan membutuhkan orang yang senang mengatur dan memerintah.

6) Memberikan hadiah utama kepada kelompok pemenang, serta memberiakan hadiah kepada seluruh lansia peserta kegiatan.

Secara keseluruhan, kegiatanmenunjukkan bahwa Terapi aktivitas kelompok, senam sehat, mampu memciptakan suasana ceriah, bahagia, dan meningkatkan semangat hidup lansia dalam kehidupan sehari-hari, sehingga menjadi stimulus untuk meningkatkan fungsi kognitif lansia. Hal ini sesuai dengan penelitian Putra, (2017). bahwa terapi aktivitas kelompok mampu meningkatkan fungsi kognitif pada lansia.Seluruh lansia merasa dibutuhkan, dihargai, diperdulikan, berguna yang di ekspresikan dengan perasaansenang, gembira, dan bahagia. Berikut gambar pelaksanaan kegiatan:

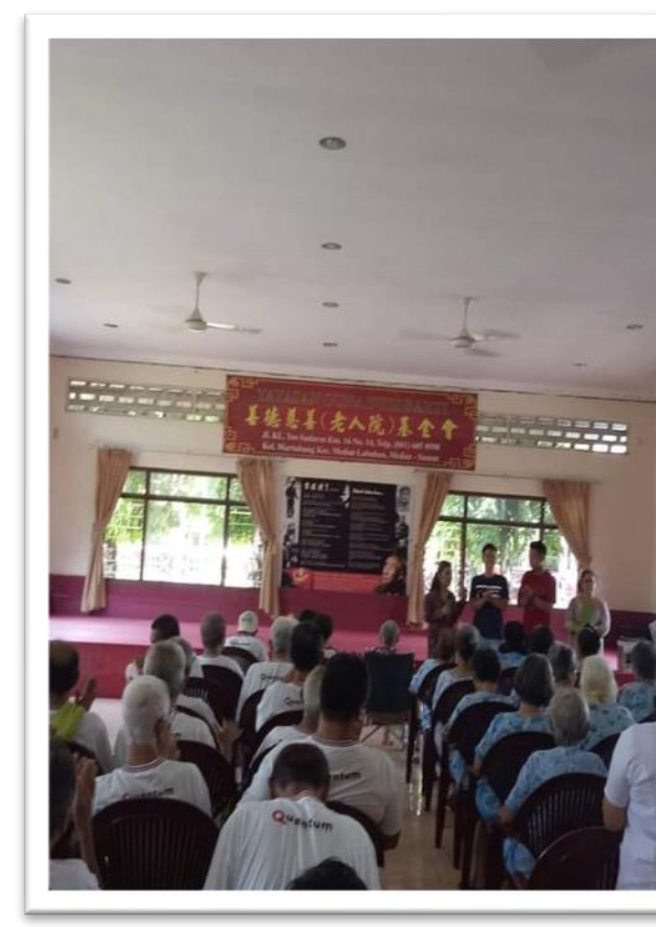

Gambar 1. Edukasi dan penjelasan kegiatan

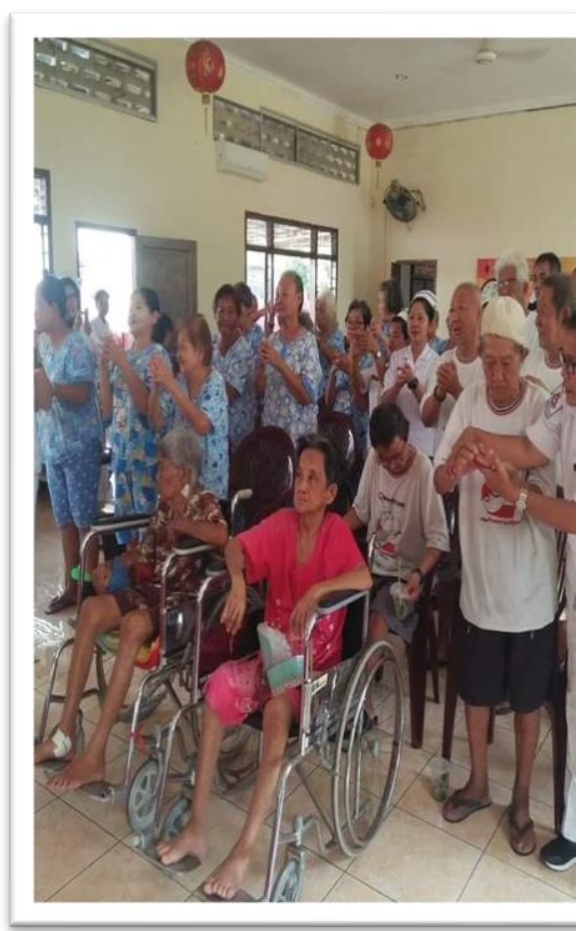

Gambar 2: Senam sehat 


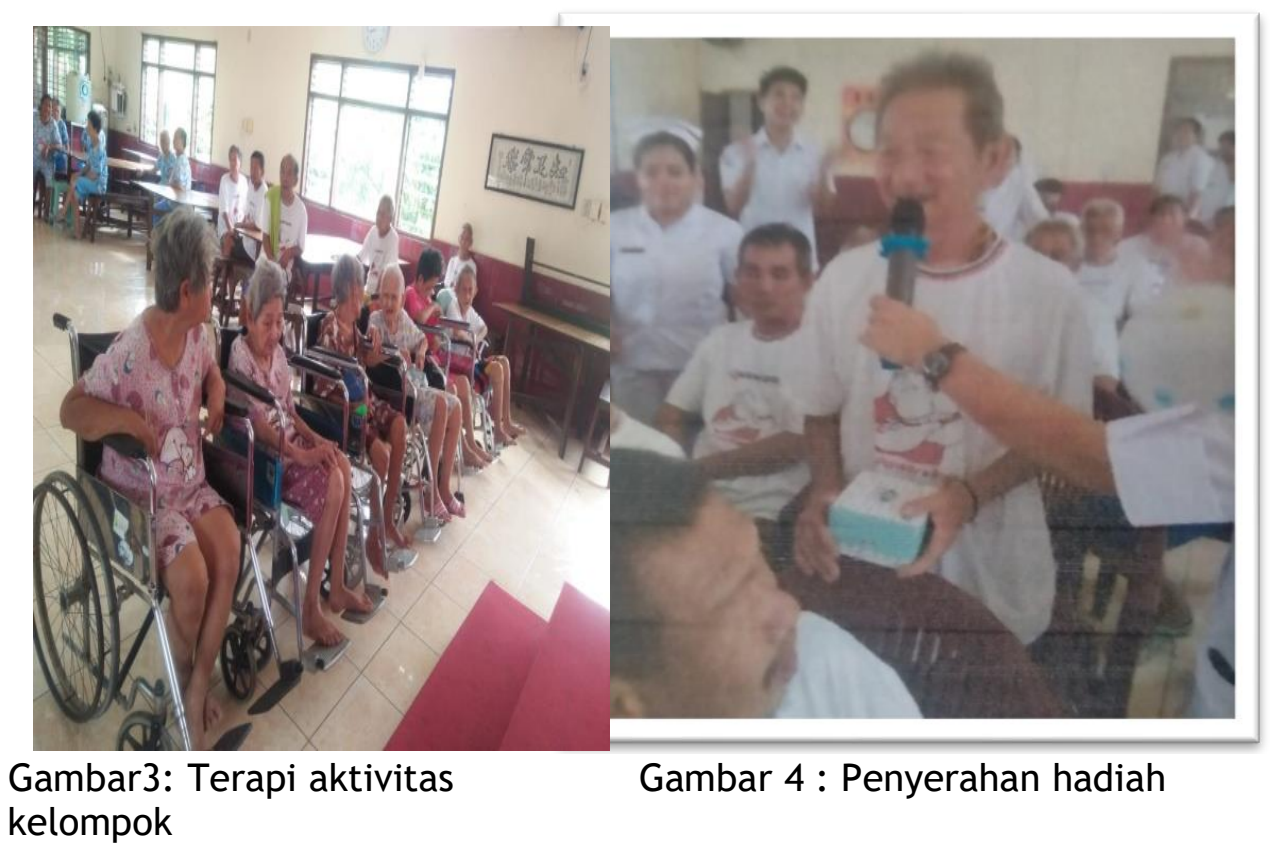

Evaluasi Hasil.

Pada akhir kegiatan, maka dilakukan evaluasi terhadap semua tindakan yang dilakukan. Evaluasi ini bertujuan untuk menilai hasil bagaimana penerimaan dan kemampuan lansia menerapkan terapi aktivitas kelompok dan senam sehat, serta sejauhmana manfaat yang dirasakan lansia setelah dialkukan kegiatan.

Terapi aktivitas kelompok (TAK) adalah kegiatan yang diberikan kelompok denganmaksud memberi terapi bagi anggota dengan tujuan untuk dapat memberikan terapi bagi seluruh anggota di dalam kelompok tersebut. Terapi ini bertujuan untuk merangsang daya ingat, kemampuan memecahkan masalah, serta kemampuan bahasa melalui penerapan terapi aktivitas kelompok dan olah raga bersama. Hal tersebut dilakukan untuk meningkatkan kualitas hidup serta meningkatkan respon sosialnya.Terapi aktivitas kelompok ini berupaya memfasilitasi beberapa lansia yang bertujuan untuk membina hubungan sosial dengan orang lain. Hal ini sejalan dengan penelitian yang dilakukan Prambudi (2017) bahwa kemampuan interaksi sosial setelah mengikuti TAK memiliki kemampuan interaksi sosial yang baik. Hal ini akan berdampak terhadap peningkatan kesehatan lansia baik secara fisik maupun mental. Selaras dengan penelitian Suzana (2016) bahwa terapi kativitas kelompok stimulasi harga diri rendah dan terapi kognitif baik untuk meningkatkan harga diri lansia yang mengalami permasalahan psikososial. Selain itu, penting pengetahuan seseorang dapat di peroleh dari berbagai media TV, penyuluhan kesehatan dalam upaya meningkatkan pengetahuan lansia akan pentingnya interaksi sosial di mana lansia berada. Hal ini sejalan dengan penyuluhan kesehatan yang dilakukan Putri, (2020) bahwa pendidikan kesehatan tentang pola sehat lansia melalui penyuluhan secara langsung, penting dilakukan untuk memaksimalkan kesehatan lansia. 


\section{KESIMPULAN}

Kegiatan pengabdian masyarakat dengan topik "Penerapan Terapi

Aktivitas Kelompok (TAK) dan Senam Lansia Sebagai Upaya Pengendalian

Demensia" dapat disimpulkan sebagai berikut:

1) Kegiatan berjalan dengan lancar sampai tahap akhirkegiatan dilaksanakan lansia tampak semangat dan berbahagia.

2) Kegiatan TAK dan senam sehat mampu meningkatkan semangat dan menciptakan kebersamaan sesama lansia selama berada di rumah Jompo

3) Semua peserta dan tim PKM mampu bekerjasama selama kegiatan berlangsung.

4) Kegiatan bermain dengan terapi aktivitas kelompok, penting di lakukan secara berkelanjutan, mengingat salah satu fungsi TAK adalah untuk meningkatkan kualitas hidup dan meningkatkan respon sosial dan kognitif. Senam lansia perlu dilakukan secara teratur, dilakukan bersama-sama, selain bertujuan meningkatkan kebugaran, juga menanamkan rasa memiliki sesama lansia di lingkungan interaksinya.

\section{DAFTAR PUSTAKA}

Apriance (2018). Hubungan dimensia dengan kebermaknaan hidup lansia di BPLU. Jurnal Keperawatan Unsrat 2018: 6(1)

Azizah, Lilik. (2011). Keperawatan Lanjut Usia. Penerbit Graha Ilmu.Yogyakarta. Nanthamongkolchai, S., Nanthamongkolchai, S., Tuntichaivanit, C., Munsawaengsub, C., Munsawaengsub, C., Charupoonphol, P., \& Charupoonphol, P. (2009). Factors Influencing Life Happiness Among Elderly Female in Rayong Province, Thailand.

Nugroho, W.(2008). Keperawatan Gerontik \& Geriatrik, Edisi 3. Jakarta: EGC.

Potter, Perry, (2009). Fundamental Keperawatan. Buku 3 Edisi 7. Jakarta: Salemba Medika

Putra,G.S.M., Indarwati,R., \& Mar'ah,E.M. (2017). Reminiscence Therapy dengan Metode Terapi Aktivitas Kelompok Meningkatkan Fungsi Kognitif Pada Lansia. Jurnal Ners,4(3)

Prambudi,W,E., Dewi,E.I., \& Sulistyorini, L. (2017). Pengaruh Terapi Aktivitas Kelompok Sosialisasi (TAKS) Terhadap Kemampuan Interaksi Sosial pada Lansia dengan Kesepian di Pelayanann Sosial Lanjut Usia (PSLU) Jember. Pustaka Kesehatan 5(2), 253-259.

Riskesdas, (2006). Laporan Nasional, Jakarta: Badan Penelitian dan Pengembangan Kesehatan Kementerian Kesehatan RI.

Sigalingging, G., Nasution, Z., \& Pasaribu, R. (2020). Harga diri (self esteem) Lansia yang Mengalami Demensia. Holistik Jurnal Kesehatan, 14(1),59-66.

Sigalingging, G. (2017). Determinan Depresi pada Lanjut Usia di Panti Jompo Harapan Jaya Marelan Medan." An-Nadaa: Jurnal Kesehatan Masyarakat, $4(1), 6-10$.

Putri,D . U. P., Setiaji, B., Maritasari, D. Y., \& Budiati, E. (2020). Penyuluhan Kesehatan Pola Hidup Sehat Pada Lansia Di Panti Tresna Werdha Natar Lampung Selatan . : Jurnal Kreativitas Pengabdian Kepada Masyarakat (PKM), 3(1), 113-118.

Suzanna,S., Mustikasari,M., \&Wardani,I.Y. (2016). Penurunan Depresi pada Lansia Harga Diri Rendahmelalui Terapi Aktivitas Kelompok Dan Terapi Kognitif. Jurnal Keperawatan Indonesia,19(3), 184-190.

Syam'ani, 2011. Studi Fenomenologi tentang Pengalaman Menghadapi Perubahan Konsep Diri:Harga Diri Rendah pada Lansia di Kecamatan. 